\title{
Physicochemical Properties and Heavy Metal Analysis of Major Water Sources in Ohaozara, Ebonyi State Nigeria
}

\author{
${ }^{1}$ Igwenyi. I. O. And ${ }^{2}$ Aja-Okorie. \\ ${ }^{1}$ Department of Biochemistry, ${ }^{2}$ Department of Agricultural Economics, Extension and Management, Ebonyi \\ State University, Abakaliki, Ebonyi State Nigeria.
}

\begin{abstract}
Water samples from various sources in Ohaozara Local Government Area of Ebonyi State Nigeria were analyzed using standard methods. These sources are used for agricultural, domestic and commercial purposes and were analyzed for physicochemical properties as well as some heavy metals contents. The $\mathrm{pH}$ of all the samples was highly alkaline and hardness was soft with moderate levels of total dissolved solids (TDS), total suspended solids (TSS) and low conductivity. The levels of iron, sulphate, copper and magnesium were generally low and normal in all the water samples. The level of nitrate was high when compared to the standard recommended level for safe drinking water. Heavy metal analyses revealed presence of arsenic and lead. The results of the physicochemical properties were within the recommended levels for safe drinking or portable water except for nitrates and heavy metals. Therefore, the water sources were not good for domestic and portable water, especially for children. This could be the cause of poor intelligent quotient and certain abnormal symptoms in the area that are attributed to evil medicine.
\end{abstract}

Key words: water, properties, heavy metals, Okposi, Uburu, Ohaozara.

\section{Introduction}

Good drinking water quality is essential for the well-being of all world people. In Nigeria, most drinking water sources have been contaminated and this has impacted on the health and economic status of the people. Drinking water from ground water sources such as well, borehole, streams and rivers provide a significant potential exposure to environmental contaminants. It has been estimated that up to $20 \%$ of human exposures can come from these routes and it is certainly higher for infants whose formula is prepared with water (Shyamala et al, 2008).

Fresh water has become a scarce commodity due to over exploitation and ever increasing world population. This has lead to the deterioration of surface and sub-surface water. Ground water is the major source of water in both urban and rural areas of the world. The quality of ground water is the resultant of all the processes that act on the water from the moment it condenses in the atmosphere to the time it is discharged by wells or spring and varies from place to place and with depth of the table (Jain et al., 1993).

Ground water crisis is not necessarily the result of natural factors. It has been caused by human actions which include plumbing materials for water pipelines and distribution, indiscriminate dumping of refuse in streams and rivers, as well as near or along water ways, dumping of old and condemned electronic components, mining activities and so on. Much of the ill health which affects humanity, especially in the developing countries, can be traceable to lack of safe and wholesome water supply (Shyamala et al., 2008).

Water is a good solvent and picks up impurities easily. Pure water is tasteless, colorless, and odorless and is often called the universal solvent. As water moves through soil and rock, it dissolves very small (trace) amounts of minerals and holds them in solution. Calcium and magnesium dissolved in water are the two most common minerals that contribute to "hardness" of water. The degree of hardness becomes greater as the calcium and magnesium content increase and is related to the concentration of multivalent cations dissolved in the water (Maton et al., 1993). There is potential for natural levels of these elements to be harmful to humans when in unusual higher concentrations. This may occur because ground water sources are used for drinking and other domestic purposes without a detailed chemical investigation.

In Ebonyi State Nigeria, about $98 \%$ of the people do not have access to portable water. Water fit for human consumption is called drinking water or potable water (CDC, 2006). To function properly, the body requires about seven liters of water per day to avoid dehydration; the precise amount depends on the level of activity, temperature, humidity, and other factors. The people depend on ground water sources such as wells, boreholes, ponds, streams and rivers for their daily water supplies. It is already known that ground water accounts for about $88 \%$ safe drinking water in rural areas where population is widely dispersed and the infrastructure needed for treatment and transportation of surface water do not exist (Kumar, 2004).

Okposi community is in Ohaozara Local Government Area of Ebonyi State, Nigeria. The town lies $21 \mathrm{~km}$ North of Afikpo, $75 \mathrm{~km}$ South of Enugu, and $147 \mathrm{~km}$ North-East of Owerri, Imo State and occupies a large expanse of land about 90 square kilometers. Uburu is also a rural community in Ohaozara Local Government 
Area of Ebonyi State Nigeria and shares a common boundary with Okposi. The people of the area are agrarian by nature as farming is their major economic activity.

This study seeks to determine the properties of water such as $\mathrm{pH}$, conductivity, total suspended and dissolved solids, metal ions and heavy metals such as copper, lead and arsenic. This will provide a baseline data for the evaluation of the water sources and provide useful information on the treatment procedure. It is hoped that the result will provoke further investigation into the quality of the water from the sources for domestic, agricultural and industrial applications.

MATERIALS AND METHODS: Collection of samples: the water samples were collected from the wells in the morning, after standing undisturbed overnight, and were flushed into properly washed 1liter plastic (sterilized) bottles. The streams and rivers were sampled in the same manner before recreational and other economic activities commenced.

New Market borehole is located in the new market area, near the Presbyterian Joint Hospital, Uburu (a missionary hospital). It supplies water to the people and the water though always warm, is tasteless and used for drinking and other domestic activities. Atta stream transverse all the rural villages in Okposi and their farmlands. It is surrounded by bamboo which gives it a good shade. Water runs off fast during the rainy season but dries up in the dry season, leaving pockets of ponds along the path. It is a source of water for washing and bathing but not used for cooking or drinking because it is dumping site for refuse as the major water body that runs off in the community. It is also a swimming ground when water volume increases with the rains. Mazi Awoke compound well is a seasonal source of water because it dries up during dry seasons. It serves the family and neighborhood all purposes. Amata Mgbom borehole is a family borehole that serves the village. It is used for all purposes. Esu river is an all season river. It is flanked in the banks by bamboo. It is a bit far from the residential areas but located around farm lands. Fishing, excavation of sand and transportation with canoe take place there. Vincent family well is seasonal. It is clean and serves the family and neighbors all purposes.

METHODS: the spectrophotometric methods of Milan (2005), Melton (2005) and Nollet (2007) were used in the analysis of the water samples. The electronic $\mathrm{pH}$ meter was used for the determination of the $\mathrm{pH}$. The conductivity was determined using the conductivity electronic meter. Results obtained were compared with standards for portable water.

\section{Results:}

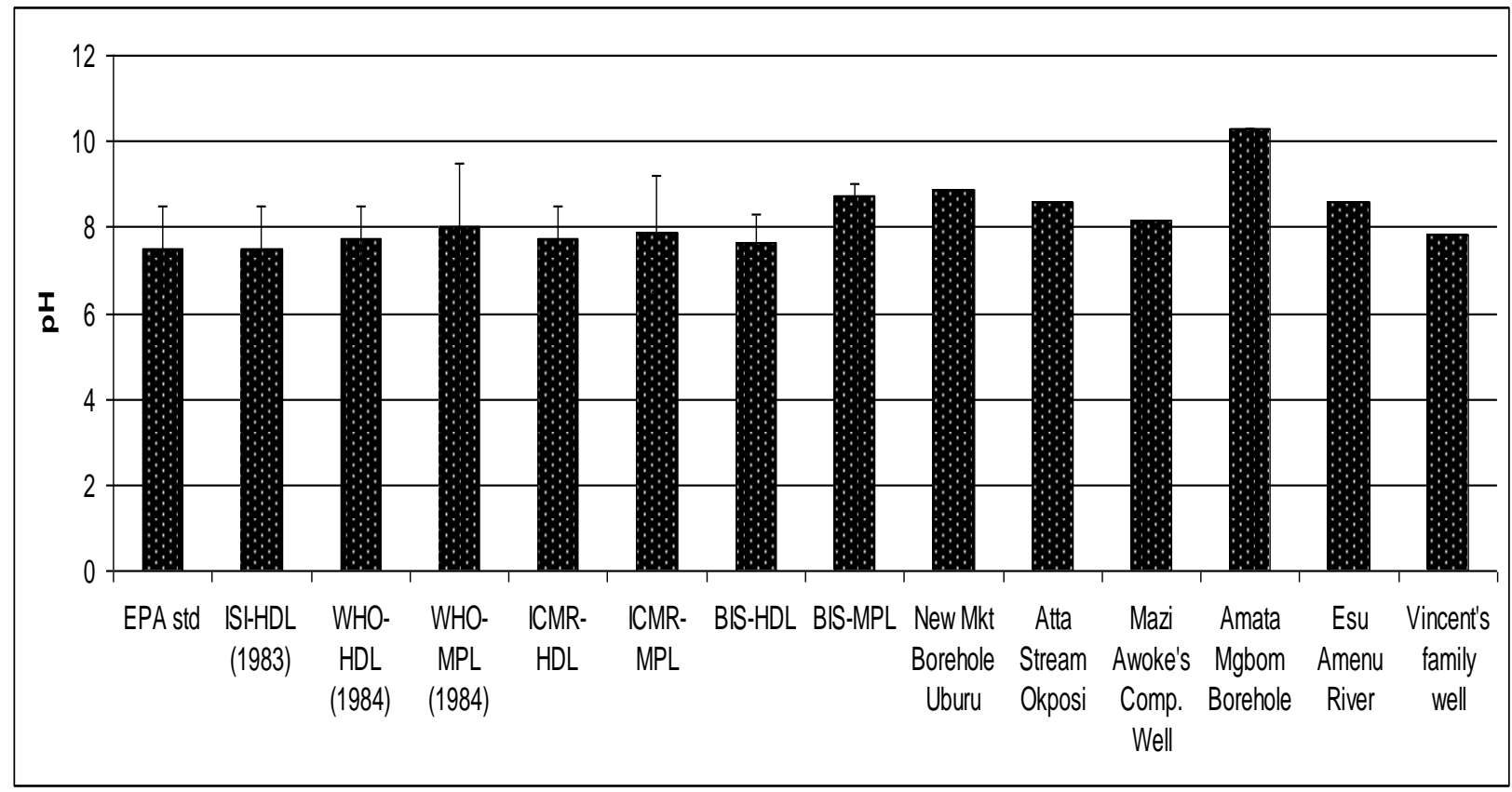

Figure 1: $\mathrm{pH}$ of the various samples compared with standard values.

Key: HDL - Highest Desirable Level; MPL - Maximum Permissible Level; EPA-United States Environmental Protection Agency; BIS - Bureau of Indian Standard; ICMR - Indian Council of Medical Research; WHO World Health Organization; ISI-Indian Standard Institute. 


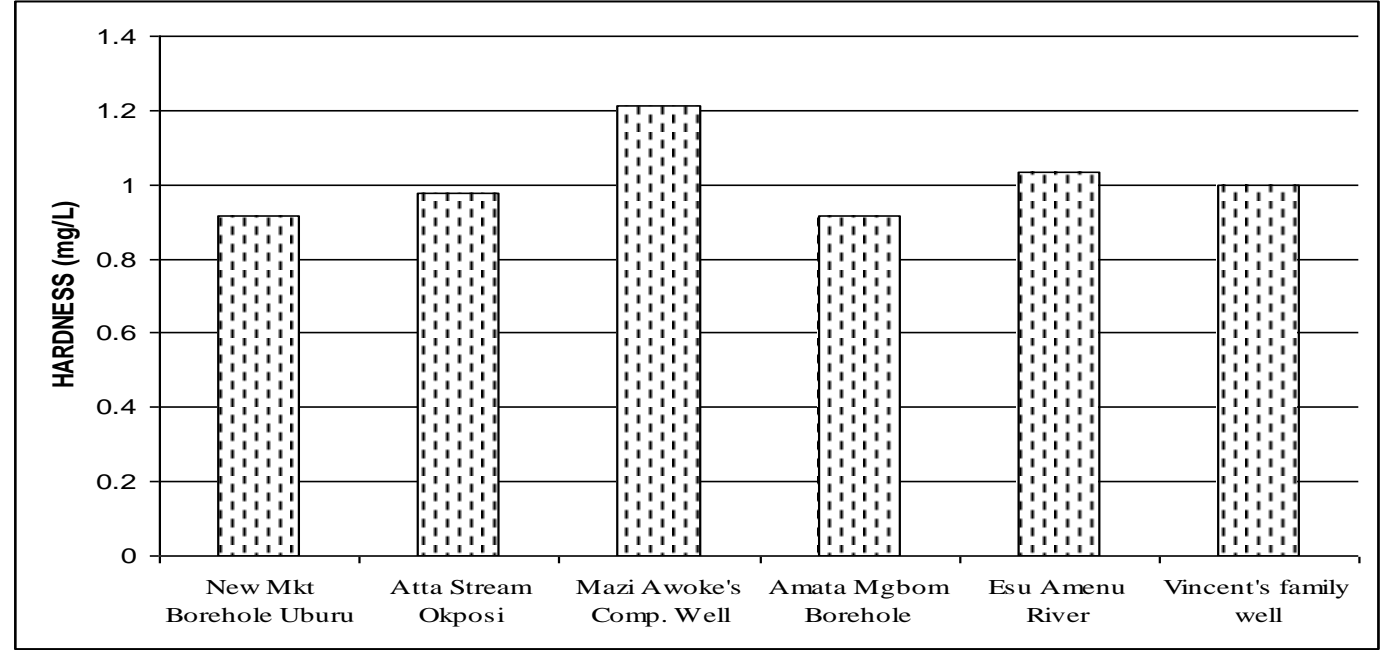

Figure 2: Hardness in $\mathrm{mg} / \mathrm{L}$ of the various water samples.

Table 1: Physical properties of the water samples.

\begin{tabular}{|l|c|c|c|c|c|}
\hline $\begin{array}{l}\text { S/N } \\
\mathbf{0}\end{array}$ & Location & $\begin{array}{c}\text { Temp } \\
\left({ }^{\mathbf{O}} \mathbf{C}\right)\end{array}$ & $\begin{array}{c}\text { Conducti } \\
\mathbf{v i t y} \\
(\mathbf{m s} / \mathbf{c m})\end{array}$ & $\begin{array}{c}\text { Total } \\
\text { Suspended } \\
\text { solids (ppm) }\end{array}$ & $\begin{array}{c}\text { Total } \\
\text { Dissolved } \\
\text { solids } \\
(\mathbf{p p m})\end{array}$ \\
\hline 1 & New Market Bore Hole, Uburu & 28 & 0.628 & 110 & 10 \\
\hline 2 & Atta Stream, Okposi & 26 & 0.553 & 200 & 50 \\
\hline 3 & Mazi Awoke's Compound well, (20ft) & 29 & 0.207 & 120 & 10 \\
\hline 4 & Okposi & -- & 0.841 & 90 & 10 \\
\hline 5 & Emata Mgbom Bore Hole, Okposi & 29 & 0.152 & 120 & 10 \\
\hline 6 & Vincent well, Amegu, Okposi & 29 & 0.321 & 100 & 10 \\
\hline
\end{tabular}

Table 2: Chemical properties of the water samples.

\begin{tabular}{|c|c|c|c|c|c|c|c|c|}
\hline S/No. & Location & $\mathrm{Fe}$ in $(\mu \mathrm{g} / \mathrm{ml})$ & $\begin{array}{l}\mathrm{SO}_{4}{ }^{2-} \text { in } \\
(\mu \mathrm{g} / 100 \mathrm{ml})\end{array}$ & $\begin{array}{l}\text { Nitrate in } \\
(\mu \mathrm{g} / 100 \mathrm{ml})\end{array}$ & $\mathrm{Cu}(\mu \mathrm{g} / \mathrm{ml})$ & Mg ( $\mu \mathrm{g} / \mathrm{ml})$ & $\begin{array}{l}\mathrm{Pb} \\
(\mu \mathrm{g} / 100 \mathrm{ml})\end{array}$ & $\begin{array}{c}\text { Arsenic } \\
(\mu \mathrm{g} / 100 \mathrm{ml})\end{array}$ \\
\hline 1 & $\begin{array}{c}\text { New Market Bore } \\
\text { Hole, Uburu }\end{array}$ & $0.195 \pm 0.001$ & $2.907 \pm 0.021$ & 239 $\pm 0.46 *$ & $0.135 \pm 0.04$ & $0.213 \pm 0.08$ & $0.003 \pm 0.00 *$ & Nil \\
\hline 2 & Atta Stream, Okposi & $0.156 \pm 0.002$ & $2.648 \pm 0.0010$ & $237 \pm 0.85^{*}$ & $0.065 \pm 0.01$ & $0.230 \pm 0.04$ & $\mathbf{0 . 0 1 3} \pm 0.00 *$ & Nil \\
\hline 3 & $\begin{array}{c}\text { Mazi Awoke's } \\
\text { Compound well, (20ft) } \\
\text { Okposi } \\
\end{array}$ & $0.188 \pm 0.002$ & -- & $296 \pm 1.02 *$ & $0.442 \pm 0.03$ & $0.219 \pm 0.03$ & $0.013 \pm 0.00^{*}$ & Nil \\
\hline 4 & $\begin{array}{c}\text { Amata Mgbom Bore } \\
\text { Hole, Okposi }\end{array}$ & $0.125 \pm 0.001$ & $2.778 \pm 0.002$ & $244 \pm 0.94 *$ & $0.246 \pm 0.02$ & $0.156 \pm 0.06$ & Nil & Nil \\
\hline 5 & $\begin{array}{l}\text { Esu Amenu River, } \\
\text { Okposi }\end{array}$ & $0.094 \pm 0.001$ & - & $340 \pm 2.46^{*}$ & $0.164 \pm 0.01$ & $0.194 \pm 0.01$ & Nil & Nil \\
\hline 6 & $\begin{array}{c}\text { Vincent well, Amegu, } \\
\text { Okposi }\end{array}$ & $0.125 \pm 0.003$ & $2.796 \pm 0.014$ & 341 $\pm 1.87 *$ & $0.287 \pm 0.04$ & $0.200 \pm 0.01$ & Nil & Nil \\
\hline
\end{tabular}

* Indicates levels above recommended limits of EPA, 2003.

\section{Discussion}

The $\mathrm{pH}$ of all the samples as shown in figure 1 was highly alkaline and hardness was soft with moderate levels of TDS and TSS and a low conductivity. However, only the $\mathrm{pH}$ of Amatta Mgbom Borehole was slightly above the highest desirable level and EPA standard (2003). $\mathrm{pH}$ is considered as an important biochemical and ecological factor and provides an important information in many types of geochemical equilibrium, solubility and concentration calculations. It is an important parameter in water body since most of the aquatic life are adapted to an average $\mathrm{pH}$ and do not withstand drastic changes (Shyalama et al., 2008). Bioconversions of organic materials in the living system is achieved with the help of enzymes which are specific in action and work within a given $\mathrm{pH}$ range (Voet and Voet, 2004).

The levels of iron, sulphate, copper and magnesium table 2 were low and normal in all the water samples. The level of nitrate was observed to be very high when compared to the standard recommended level 
for safe drinking water. Arsenic was generally absentt in all water samples while Lead was present in Uburu New Market borehole, Atta river water and Mazi Awoke's compound well in Amenu Okposi.

Nitrate contamination is a typical problem in agricultural areas like Ohaozara and the sources may come from excessive or improper manure and fertilizer use, inadequate water management and erosion protection, landscaping fertilizers for lawn maintenance and airborne sources of oxides of nitrogen. However, nitrogen is needed by every living plant and animal and can be found in the soil, air, rain and water bodies. Elevated level of nitrate or nitrite in infants or babies could lead to death from the disease called "methemoglobinema", a condition whereby the hemoglobin is unable to carry oxygen throughout the body, leading to suffocation and death due to lack of oxygen (CHSDEP of EPA, 2003). Nitrite is absorbed into the body when in excess and reacts with the blood (hemoglobin) to form methemoglobin causing "Blue Baby Syndrome" (Burtis and Ashwood, 2003). High level of nitrate in water has been related to cancer, so it is advisable to reduce exposure to sources of nitrates. Nitrate contamination is typically a problem in agricultural areas, but other rural non-agricultural communities are also at risk. Sources of nitrates include animal waste, fertilizers, natural deposits, septic tanks and sewage while the clinical manifestation shows as methemoglobinemia.

Lead is a toxic metal that is harmful to human health and there is no safe level for lead exposure. It is believed that up to $20 \%$ of the total lead exposure in children can be attributed to a waterborne route. Infants, fetuses, and young children are particularly vulnerable to lead poisoning. This is because they usually consume more water and their bodies are actively developing, which facilitates the bioaccumulation of lead. High levels of lead contamination in a child can result in convulsions, major neurological damage, organ failure, coma, and ultimately death. Moderate to low levels of exposure may result in hearing loss, growth inhibition and learning disabilities. There may be no signs of lead poisoning or the signs could mimic flu or other gastrointestinal disease (WHO, 2004). The symptoms may include: cramps, irritability, fatigue, vomiting, constipation, sleep disorder, poor appetite, and trouble sleeping (CHSDEP of EPA, 2003). Unlike other contaminants, lead will accumulate within the body over time and will tend to be stored in the brain, bones, kidneys and other major organs. It can be stored in child's blood for months and bones for many decades. Some of the effects of lead poisoning can not be cured, but it is possible to reduce exposure to lead. In the kidneys, lead decreases the ability of the kidneys to excrete uric acid (Voet and Voet, 2004).

It was observed that the results of the physicochemical properties were within the recommended levels for safe drinking or portable water by Environmental Protection Agency (EPA, 2003) except for nitrates and heavy metal Lead. Nitrate level was very high in all the samples and lead was also present in New Market borehole in Uburu, Atta river water and Mazi Awoke's compound well. The Environmental Protection Agency Standard for heavy metals in drinking water (EPA, 2003) are $\mathrm{pH}: 6.5-8.5$, Conductivity: $1 \mathrm{~ms} / \mathrm{L}$, Arsenic: $0.05 \mathrm{mg} / \mathrm{L}$, Copper: $1.30 \mathrm{mg} / \mathrm{L}$, Iron: $0.30 \mathrm{mg} / \mathrm{L}$, Lead: 0.000mg/L, TDS: $500 \mathrm{mg} / \mathrm{L}$, Manganese: $0.05 \mathrm{mg} / \mathrm{L}$, Sulphate: $250 \mathrm{mg} / \mathrm{L}$, Nitrate: $10 \mathrm{mg} / \mathrm{L}$, Hardness: 0 to 17.10 (soft hardened), 17.10 to $60 \mathrm{mg} / \mathrm{L}$ or ppm, (Slightly hard), 60 to $120 \mathrm{mg} / \mathrm{L}$ (Moderately hard), 120 to $180 \mathrm{mg} / \mathrm{L}$ (Hard), 180 and over $\mathrm{mg} / \mathrm{L}$ (very hard).

It is therefore recommended that the water sources are not good for domestic and portable water supply, especially for children while those that contained lead are not safe at all. This could be the cause of certain abnormal symptoms in the area that are attributed to evil medicine. The ways to prevent this contamination of these water sources include: proper refuse (including electronic components) and sewage disposal, proper siting of water systems, proper handling of fertilizers and manure, proper well construction (sanitary wells), and installation of point-of-use water treatment devices. The primary water treatment devices for nitrate removal include: ion exchange resins, distillation, and reverse osmosis.

\section{References}

[1] Bryant, M. (2005). Water and salt. In: Horwitz M and Latiner G. W. (eds). Official methods of analysis of AOAC International, $18^{\text {th }}$ edition, AOAC International, Maryland, USA, $1-32$.

[2] Burtis, C. A. and Ashwood, E. R. (2003). TIETZ Fundamentals of clinical chemistry, $5^{\text {th }}$ edition. Elsevier, New Delhi, India.

[3] CDC, (2006). U.S. Center for Disease Control and Prevention. Atlanta, GA. "Safe Water System: A Low-Cost Technology for Safe Drinking Water." Fact Sheet, World Water Forum 4 Update. March 2006.

[4] CHSDEP of EPA (2003). County Health and State Department of Environmental Protection, Environmental Quality Center, Wilkes University (570) 408-4619.

[5] Ihnat, M. (2005). Metals and other elements at trace levels in food. :In: Horwitz M and Latiner G. W. (eds). Official methods of analysis of AOAC International, $18^{\text {th }}$ edition, AOAC International, Maryland, USA, $1-62$.

[6] Jain, C. K., Bhatia, K. K. S. and Vijay, T. (1995). Ground water quality monitoring and evaluation in and around Kakinnada, Andhra Predesh Technical report, CSCAR, 172, National Institute of Hydrology, ROORKEE, 1994-1995.

[7] Maton, A. B. J., Jean, H., Charles, W. M.., Susan, J., Maryanna, Q., Warner, D. L. and Jill, D. W. (1993). Human Biology and Health. Englewood Cliffs, New Jersey, USA: Prentice Hall.

[8] Nollet, L. M. L. (2007). Handbook of water analysis, $2^{\text {nd }}$ edition, CRC Press, London. 219-312.

[9] Kumar, A. (2004). Water pollution. Nisha Enterprises, New Delhi, 1-331.

[10] Shyamala, R., Shanthi, M. and Lalitha, P. (2008). Physiochemical analysis of borewell water samples of Telugupalayan area in Coimbatore district, Tamilnadu, India, E-Journal of Chemistry, 5(4): 924-929.

[11] Voet, D. and Voet, J. G. (2004). Biochemistry. $3^{\text {rd }}$ Edition, John Wiley and Sons Inc., U.S.A.

[12] World Health Organization (WHO). (2004). Geneva, Switzerland. In: Joyce, M. D., Charles, O. A., Peter, L. and George, H. "The contribution of drinking-water to total dietary intakes of selected trace mineral nutrients in the United States." Draft, August 2004. 